Jurnal Konstruksi Hukum | ISSN: XXXX | E-ISSN: XXXX Vol. 1, No. 2, Oktober 2020, Hal. 374-378| Available online at https://www.ejournal.warmadewa.ac.id/index.php/jukonhum DOI: https://doi.org/10.22225/jkh.1.2.2546.374-378

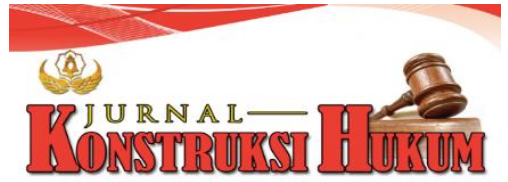

\title{
KEBIJAKAN HUKUM PIDANA DALAM PENANGGULANGAN TINDAK PIDANA PERDAGANGAN ANAK
}

\author{
I Ketut Eka Yoga Juliantika, I Made Sepud, Ketut Sukadana \\ Fakultas Hukum Universitas Warmadewa, Denpasar-Bali, Indonesia
}

\begin{abstract}
Abstrak
Anak sering menjadi korban Tindak Pidana perdagangan Anak. Ada banyak factor yang mendukung terjadinya Tindak Pidana Perdagangan Anak salah satunya kurangnya pengaturan tetang perdagangan anak. Berdasarkan latar belakang tersebut, penelitian ini dilakukan dengan tujuan mendeskripsikan bagaimana pengaturan tindak pidana perdagangan anak (child trafficking) dan bagaimana kebijakan hukum pidana terhadap tindak pidana perdagangan anak (child trafficking). Penelitian ini didesain dengan menggunakan metode penelitian hukum normatif. Hasil penelitian ini menunjukkan bahwa pengaturan tindak pidana perdagangan anak (child trafficking) diatur dalam UU No. 21 Tahun 2007 tentang Pemberantasan Tindak Pidana Perdagangan Orang, Kitab UU Hukum Pidana (KUHP) yakni Pasal 297, Pasal 301, Pasal 324, Pasal 328, dan Pasal 330, UU RI No. 21 Tahun 2007 tentang Pemberantasan Tindak Pidana Perdagangan Orang, UU No. 35 tahun 2014 atas Perubahan UU No. 23 Tahun 2002 tentang Perlindungan Anak, dan UU No. 11 Tahun 2012 tentang Sistem Peradilan Pidana Anak. Selanjutnya, kebijakan hukum pidana terhadap tindak pidana perdagangan anak (child trafficking) diatur dalam Kitab UU Hukum Pidana, Kitab UU hukum Acara Pidana, UU No. 21 Tahun 2007 tentang Pemberantasan Tindak Pidana Perdagangan Orang, UU No. 11 Tahun 2012 tentang Sistem Peradilan Pidana anak, dan UU No. 35 Tahun 2014 tentang perubahan terhadap atas UU No. 23 Tahun 2002 tentang Perlindungan Anak.
\end{abstract}

Kata Kunci: Kebijakan; Tindak Pidana; Perdagangan Anak

\begin{abstract}
Children are often victims of child trafficking crime. There are a lot of factors that support the crime of child trafficking, one of which is the lack of regulation on child trafficking. Based on this background, this research was conducted with the aim of describing how the regulation of child trafficking and how the criminal law policy against child trafficking. This research was designed using a normative legal research method. The results of this study indicated that the regulation of child trafficking is regulated in Law No. 21 of 2007 concerning the Eradication of the Crime of Trafficking in Persons, the Criminal Code (KUHP), namely Article 297, Article 301, Article 324, Article 328, and Article 330, RI Law No. 21 of 2007 concerning the Eradication of the Crime of Trafficking in Persons, Law No. 35 of 2014 on Amendments to Law no. 23 of 2002 concerning Child Protection, and Law no. 11 of 2012 concerning the Juvenile Criminal Justice System. Furthermore, the criminal law policy against child trafficking is regulated in the Criminal Code, the Criminal Procedure Code, Law no. 21 of 2007 concerning the Eradication of the Crime of Trafficking in Persons, Law no. 11 of 2012 concerning the Child Criminal Justice System, and Law no. 35 of 2014 concerning amendments to Law no. 23 of 2002 concerning Child Protection.
\end{abstract}

Keywords: Policy; Crime; Child Trafficking

\section{PENDAHULUAN}

Negara Indonesia menjadi tempat yang strategis untuk melakukan perdagangan internasional dikarenakan banyaknya perbatasan dengan negara-negara, maka dari itulah Indonesia memiliki tidak hanya keuntungan, tetapi juga memiliki kerugian-kerugian (Wangke, 2013). Kerugian tersebut berkembang menjadi isu-isu nasional contohnya adalah perdagangan orang yang mengkhusus kepada perdagangan anak. Globalisasi yang tidak bisa dihindari membuat negara-negara melakukan perdagangan internasional baik itu barang dan jasa, namun juga termasuk pada tenaga kerja dan arus modal yang dimiliki (Warni \& Setyari, 2019).

Kebijakan Internasional suatu Negara berdasarkan yuridiksi teritorial meemiliki hak, kekuasaan, atau kewenangan untuk membuat atau menetapkan peraturan perundang-undangan atau keputusan- 
keputusan untuk diberlakukan dalam batas teritorialnya, dilaksanakan terhadap orang dan atau badan badan hukum serta mengadili pelaku kejahatan dimuka penegak hukum yang berwenang dalam teritorialnya (Hamzah, 2005). Akan tetapi, tidak dapat sering dilakukan dikarenakan pelaku kejahatan telah melarikan atau disebut fugitive ke yuridiksi territorial negara lain (Ariyanti, 2019).

Suatu negara tidak bisasewenang-wenang melaksanakan penegakan hukumnya yang bersifat kedaulatan diwilayah negara lain (Novianto et al., 2020). Aparat penegk hukum suatu negara ketika penangkapan pelaku kejahatan hampir mustahil atau sulit dilakukan karena yuridisi kerjasama berdasarkan atas dasar pemikiran tersebut, Indonesia juga merupakan sebuah Negara yang banyak memiliki kasus perdagangan anak, juga sudah membentuk organisasi untuk melindungi hak anak tersebut yaitu KPAI (Komnas Perlindungan Anak Indonesia), KPAI merupakan lembaga khusus yang independen mengefektifkan perlindungan anak. Peraturan yang menjadi pijakan pergerakan Komisi Perlindungan Anak Indonesia (KPAI) sesuai dengan amanat UU No. 17 Tahun 2006 tentang penetapan peraturan pemerintah pengganti UU No. 1 Tahun 2016 tentang perubahan kedua atas UU No. 23 Tahun 2002 tentang perlindungan anak.

Terkait penelitian ini ada beberapa peneliti terdahulu melakukan penelitian yang relevan dengan penelitian ini yaitu penelitiannya mengungkapkan bahwa Kebijakan penanggulangan tindak pidana perdagangan bayi dalam hukum pidana di masa mendatang, baik itu dalam konsep KUHP tahun 2004 maupun dalam RUU Pemberantasan perdagangan perempuan dan Anak belum ada pasal yang khusus mengatur perdagangan bayi, oleh sebab itu perlu dikaji kembali dan perlu adanya perbandingan dengan negara lain untuk mencapai hasil yang maksimal. Pada tahun (Novianto et al., 2020). Penelitian kedua mengkaji mengkaji tentang pembaharuan kebijakan pidana kejahatan perdagangan orang (Azizurrahman, 2014). Selanjutnaya penelitian yang mengkaji kebijakan hukum pidana dalam menanggulangi tindak pidana perdagangan bayi (Herlina, 2006).

Pembahasan mengenai komisi perlindungan anak Indonesia terdapat pada BAB XI yang khusus membahas mengenai komisi ini. Dasar pembentukan KPAI di jelaskan pada Pasal 74, dari pasal tersebut dapat dilihat dari pembentukan KPAI adalah untuk mengefektifkan penyelenggaraan Perlindungan Anak sehingga hak-hak anak dapat terjamin. Dari pasal tersebut juga disebutkan bahwa lembaga ini merupakan lembaga independen, sehingga keberadaanya bebas dari intervensi dari pihak lain. Penelitian ini bertujuan untuk mengetahui pengaturan tindak pidana perdagangann anak (child traffficing) serta mengidentifikasi dan menjelaskan kebijakan hukum pidana perdagangan anak (child trafficking).

\section{METODE PENELITIAN}

Penelitian ini menggunakan jenis penelitian hukum normative yaitu penelitian yang berfokus pada masalah yang diteliti, dengan menggunakan pendekatan perundang-undangan, konseptual yang beranjak dari pandangan-pandangan dan doktrin-doktrin yang berkembang di dalam ilmu hukum dan pendekatan kasus. Sumber data yaitu bahan hukum primer dan sekunder. Teknik pengumpulan data dilakukan melalui inventarisasi atau penelusuran bahhan hukum yang bersangkutan menggunakan soft copy lalu diklasifikasi atau dikelompokan dan didokumentasikan, dicatat, dikutip, diringkas, diulas sesuai kebutuhan dengan pendekatan kualitatif yang menghasilkan data deskriptif analitis, selanjutnya teknik analisis data yang digunakan adalah teknik argumentasi hukum dan teknik penemuan hukum.

\section{HASIL DAN PEMBAHASAN}

\section{Pengaturan Tindak Pidana Perdagangan Anak (Child Trafficking)}

Perdagangan anak merupakan penempatan, pemindahan untuk tujuan ekploitasi terhadap anak dengan menggunakan paksaan dan kekerasan dan di tujukan kepada siapapun atau kelompok demi keuntungan atau dalam bentuk (Gultom, 2012). Penanggulangan tindak pidana dapat diawali dari pencegahan dan diakhiri dengan penindakan hukum. Perdagangan anak dapat terjadi dalam berbagai peristiwa hukum seperti: penjualan anak yang merupakan tindakan atau transaksi yang memindahkan anak kepada orang lain demi keuntungan bersifat ekonomis atau keuntungan lain, penyelundupan anak yang merupakan usaha untuk mendapatkan keuntungan-keuntungan dengan menempatkan anak secara tidak resmi dan migrasi yang dalam arti disini adalah proses anak atas tekanna atau paksaan memilih untuk tinggal dan pergi ke tempat lain. Penanggulangan tindak pidana dapat meliputi hukum piidana pormal dan materiil, untuk pengaturan hukum tindak pidana perdagangan orang di atur dalam UU No. 21 tahun 2007. (Romli, 1995). 
Merujuk kepada pengaturan hukum perdagangan orang kurang membahas tentang perdagangan anak maka perlulah suatu pembentukan pengaturan tentang perdagangan anak, tindak pidana perdagangan orang memuat aspek-aspek yang bertentangan dengan perlindungan dan juga berlawanan dengan kesejahteraan umum. pengaturan hukum perdagangan orang sampai saat ini menjadi pembahasan dikarenakan kurang lengkap dan menyeluruhnya pembahasan mengenai pelanggaran HAM dan anak maka dari itu memerlukan regulasi dengan cara mengubah dan menambah peraturan yang berhubungan dengan hal itu atau dapat membentuk kembali pengaturan khusus mengenai anak dengan menambahkan konsep HAM dalam pengaturan perdagangan orang dan Perdagangan Anak, dengan mengacu kepada hukum naional dan hukum internasional. Namun terdapat kemajuan dalam Undang-Undang perdagangan anak, salah satu kemajuan tersebut adalah ancaman pidana bagi pelaku perdagangan orang mempunyai pidana minimal hingga pidana maksimal serta sang korban berhak mendapatkan kovensasi dari negara dan resitusi serta ganti rugi dari sang pelaku. Selain itu UU perdagangan orang juga memberikan peluang agar pemerintah dapat mengusahakan dan memberikan perlindungan bagi korban, saksi maupun pelapor. Tidak hanya itu penerapan hukuman pada kasus perdagangan orang juga di kenal dalam hukum pidana Indonesia. Kebijakan seperti diatas sangat baik juka diterapkan juga pada Undang-Undang perdagangan anak (Apriani, 2017).

Perdagangan anak identik dengan perbudakan. Undang-undang yang dapat mengakomodasi perbudakan atau perdagangan anak tersebut adalah Undang-Undang No. 23 Tahun 2002 tentang perlindungan anak, tetapi Undang-Undang ini dan juga KUHP tidak cukup merinci tentang kebijakan perdagangan anak selain melihat beberapa peraturan tersebut haruslah juga melihat konvensi hak-hak anak mengenai ppenjualan anak, prostitusi anak dan pornografi anak sebagai upaya perlindungan anak sebagai korban perdagangan anak. Eksploitasi Seksual pada anak adalah melibatkan sang anak dalam pelayan seksual atau prostitusi atau dapat berupa sebagai objek pornografi yang dikarenakan oleh ancaman, paksaan, penculikan dengan tujuan mendapatkan hasil bersifat ekonomis dan keuntungan lain dari melacurkan sang anak. Adapun eksploitasi lainnya berupa kerja paksa, perbudakan, penghambaan, atau penjualan organ tubuh pengertian terdapat dalam instrumen-instrumen hukum internasional lainnya. Pengaturan perdagangan anak mengacu kepada pengaturan perdagangan orang yaitu UndangUndang No. 21 Tahun 2007 tentang pemberantasaan tindak pidana perdagangan orang. Selain itu terdapat pengaturan hukum yang terkait dengan perdagangan anak dan perlindungannya yaitu KUHP (KUHP), Undang-Undang Perlindungan Anak, Undang-Undag sistem peradilan pidana anak dan mengacu kepada konvensi hak-hak anak.

\section{Kebijakan Hukum Pidana terhadap Tindak Pidana Perdagangan Anak (Child Trafficking)}

Unsur-Unsur tindak pidana perdagangan anak dapat dibuktikan dengan pernyataan dan keterangan korban tetapi dalam prakteknya keterangan tersebut menjadi penyebab bingungnya dalam membuktikan tindak pidana tersebut karena sang anak memikirkan ancaman-ancaman dari pelaku selain itu pernyataan dengan mengarah pada tujuan korban dapat menjadi pendukung pembuktian.dari hal tersebut penggunaan kebijakan sebagai salah satu upya mengatasi masalah sosial termasuk dalam bidang penegakan dan perlindungan hukum dengan tujuan mencapai kesejahteraan masyarakat pada umumnya, maka kebijakan penegakan hukum termasuk dalam bidang kebijakan sosial sebagaisegala usaha rasional mencapai cita-cita bangsa. Kebijakan dalam mengulangin suatu msalah hukum pidana hendaknya menjdai keharusan. Perlindungan yang konkret pada dasarnya merupakan perrlindungan yang hanya bisa dinikmati secara nyata. Perlindungan abstrak pada dasarnya hanya bisa di nikmati secara emosional. Selain perlindungan ini terdapat perlindungan yang dapat di berikan olehh Indone Peraturan perundang-undangan.

Perlindungan ini berupa kebijakan yang dapat di gunakan dalam perlindungan korban pada tindak pidana perdagangan anak yaitu pertama Kitab UU Hukum Pidana (KUHP) pada pasal 297, 301, 324, 326 s.d 333, kedua Kitab UU Hukum Acara Pidana (KUHAP) pada pasal 98 s.d 101, ketiga UU No. 21 tahun 2007 tentang Pembrantasan Tindak Pidana Perdagangan Orang pada pasal 2 s.d 6, pasal 9 s.d 12, pasal 17, pasal 19 s.d 24, keempat UU No. 11 Tahun 2012 tentang Sistem Peradilan Pidana Anak pada pasal 1 ayat (4), pasal 2, pasal 3, pasal 4 ayat (1), pasal 6, pasal 18, pasal 19, pasal 21, pasal 22, pasal 30, pasal 40, pasal,79, pasal 89 dan dalam UU perlindungan anak dalam pasal 78 dan pasal 83.

Dalam perlindungan hukum bagi anak yang menjadi korban perdagangan anak bisa membandingkan Undang-Undang dengan konvensi hak-hak anak dengan mengguanakan asas-asas yaitu asas non diskriminasi, asas kepentingan yang terbaik bagi anak, asas hak untuk hidup, asas 
penghargaan atas hak anak lalu dapat merujuk kepada UU No. 1 Tahunn 2000 tentang retifikasi konvensi ILO (Internatiional Labour Organitation) untuk melindungi anak dalam kasus eksploitasi seksual komersil pada konvensi hak-hak anak mengenai eksploitasi terkandung dalam pasal 34 dan 36. Ditekankan kembali pada Pasal 66 ayat (1) bahwa perlindungan khusus bagi anak yang di eksploitasi secara ekonomi dan seksual sebagaimana dimaksud dengan Pasal 59 tidak hanya menjadi kewajiban dan tanggung jawab masyarakat.

Maka dari itu diperlukan mekanisme dalam menanggulangi kejahatan perdagangan anak yaitu dengan membentuk Undang-Undang tentang kejahatan perdagangan anak untuk melindungi anak ketentuan yang menyatakan tentang perdagangan anak terdapat dalam konvensi hak-hak anak mengenai anak, pelacuran anak, pornografi anak yang telah ditandatangani pemerintah Indonesia pada tanggal 24 september 2001 dalam pasal 2 (a) yang menyatakan Bahwa penjualan anak adalah segala tindakan atau transaksi dalam anak di transfer oleh segala orang atau kelompok orang ke orang lain untuk mendapat imbalan atau pertimbangan lain. Dalam UU No. 21 tahun 2007 tentang pemberantasan Tindak Pidana perdagangan orang hanya menyatakan pengiriman menjadi salah satu proses dalam perdagangan yang juga di anjam hukuman pidana, maka dari itu diperlukannya mekanisme dalam menanggulangi kejahatan perdagangan anak (Muliadi, 2008).

\section{SIMPULAN DAN SARAN}

\section{Simpulan}

Berdasarkan uraian dalam pembahasan, dapat dibuat simpulan, sebagai berikut:

1. Tindak pidana perdagangan orang merupakan tindak pidana khusus, yang diatur dalam UU No. 21 Tahun 2007 tentang pemberantasan tindak pidana perdagangan orang.

2. Kebijakan hukum pidana terhadap perdagangan anak atau mengacu kepada anak sebagai korban dari tindak pidana tersebut belum dibentuk atau diatur dalam undang-undang maka dalam melindungi anak pada kasus tindak pidana perdagangan anak dapat membandingkan hukum nasioanl dan hukum internasional. Hukum nasional kita dibandingkan dengan konvensi hak-hak anak. Dikarenakan dalam Konvensi Hak-Hak Anak dapat kita temukan pasal yang menyebutkan atau dapat menjelaskan tentang perdagangan anak yang dalam hal ini dibahas tentang pelacuran anak, porografi dalam pasal 2 (a) yang menyatkan bahwa penjualan anak adalah segala tindakan atau transaksi dimana anak di transfer oleh segala orang atau kelompok orang ke orang lain untuk mendapat imbalan atau pertimbangan lain.

\section{Saran}

Ada beberapa yang bisa disarankan oleh peneliti yaitu:

1. Mengingat anak mudah untuk menjadi objek perdagangan karena banyak faktor yang mendukung agar anak terpaksa mengikuti arahan yang melanggar hukum maka seharusnya pemerintahan mengeluarkan pengaturan khusus dalam menindak lanjuti perdagangan anak sebagai upaya pencegahan dan pemberantasan tindak pidana perdagangan anak tersebut.

2. Upaya melindungi hak hak dan kewajibanan anak dan mengingat telah terbentuknya pengaturan tentang system perlindungan anak, seharusnya terdapat kebijakan terhadap anak sebagai korban dari tindak pidana perdagangan anak yang menjadi tolak ukur hakim dalam persidangan perkara perdagangan anak.

\section{DAFTAR PUSTAKA}

Apriani, R. D. dan F. (2017). Kebijakan Nasional Anti-Trafficking dalam Migrasi Internasional. Politica, 8(2), $137-162$.

Ariyanti, V. (2019). Pembaharuan Hukum Pidana di Indonesia yang Berkeadilan Gender dalam Ranah Kebijakan Formulasi, Aplikasi, dan Eksekusi. Halu Oleo Law Review, 3(2), 178-195.

Azizurrahman, S. H. (2014). Pembaharuan Kebijakan Pidana Kejahatan Pedagangan Orang ( Studi di Wilayah Perbatasan Kalimantan Barat-Sarawak ). Yustisia, 3(2), 88-99.

Gultom, M. (2012). Perlindungan Hukum terhadap Anak dan Perempuan. Refika Aditama.

Hamzah, A. (2005). Asas-Asas Hukum Pidana. Rineka Cipta.

Herlina, H. (2006). Kebijakan Hukum Pidana dalam Menanggulangi Tindak Pidana Perdagangan Bayi. Law Reform, $1(2)$.

Muliadi, M. (2008). Pendekatan Integral Penal Policy dan Non Penal Policy dalam Penanggulangan Kejahatan Kekerasan. Pustaka Bangsa Press. 
Novianto, R. D., Firmansyah, D. A., \& Pratama, N. A. (2020). Penyelesaian Sengketa di Laut Natuna Utara. Jurnal Hukum Bisnis Bonum Commune, 3(1), 69-78.

Romli, A. (1995). Kapita Selekta KriminologiI. Mandar Maju.

Wangke, H. (2013). Perdagangan Lintas Batas Antar Negara Memacu Pembangunan Ekonomi Kabupaten Bengkayang dan Kabupaten Belu. 4(1), 1-24.

Warni, G. S., \& Setyari, N. P. W. (2019). Analisis Daya Saing Ekspor Pakaian Jadi Indonesia ke Pasar Jerman Periode Tahun 2013-2018. E-Jurnal Ekonomi Pembangunan Unversitas Udayana, 8(11), 2656-2688. 